What Affect the Discount to Net Asset Value in U. K. Listed Property Companies?

Qiulin Ke

The Bartlett School of Built Environment, University College London, UK

\begin{abstract}
In this paper, we investigate empirically the factors that affect the discount to NAV in UK listed property companies from 2005 to 2013. In this paper, we extend the previous studies on the discount to NAV in UK property companies by relating the level of NAV discount to a broader set of variables such as size, liquidity, gearing, property portfolio diversification, company's risk and return. Specially, we relate the discount to NAV to a set pf principal corporate governance mechanisms. The empirical test results report significantly positive relation between discount and gearing and risk, but negative relation with size, type of stock, level of focus on property type. Besides, a significantly negative relation can been seen between discount and corporate governance variables of board independence and institutional ownership, suggesting that the corporate governance mechanisms do matter to the discounts to NAV in the UK listed property companies, especially in the up market.
\end{abstract}

Key words: discount, NAV, UK listed property company 
What Affect the Discount to Net Asset Value in UK. Listed Property Companies?

\section{Qiulin Ke}

The Bartlett School of Built Environment, University College London, UK

Net Asset Value (NAV) is useful for the valuation of shares in sectors where the value of a company comes from the assets it holds (e.g. property companies) rather than the profit stream generated by the business. For these companies, there is normally a close correlation between the value of the property portfolio and the value of companies' shares that are priced in relation to the net asset value (NAV) rather than on a price-to-earnings. The NAV in this context represents the underlying value of the property assets owned along with other assets, adjusted for liabilities and other claims on the company. The main argument is that at a fundamental level, property company share prices must reflect their underlying property investment value. However, there has been the existence and persistence of deviation of NAV of property companies from their market capitalization. Over the last three decades, it has generally been the case in the UK that the capital market has reflected a discount to NAV in the property companies, i.e. the stock market does not always value the property company according to its fundamental value. This discount / premium to NAV varies widely from one company to another and over time. NAV is an important performance metric and the managers of property companies aim to maximise the growth of their NAV, as investors generally regard the shares of a property company as essentially claims on assets. If the property company and the underlying net assets are priced efficiently, a discount to NAV implies that properties held indirectly through the property company are less valuable than if they were held directly.

The primary activities of the UK property companies consist of the acquisition and subsequent holding of property assets, or/and purchase of property interests for resale in the short-term. Most of the UK listed property companies are non-REITs. UK REITs came into existence since $1^{\text {st }}$, January, 2007. There are only 19 REITs and only one IPO so far. UK listed property companies adopt fair value accounting to report investment portfolio in the financial report. They have their property investment assets appraised annually and provide on an annual basis an accurate estimate of their total asset value and net asset value (NAV). Unlike US REITs, new 
right shares issues are not frequently used by the UK property companies to raise capital since both directors and shareholders are reluctant to issue shares for a price below NAV and the market price of their shares frequently stands at a discount to the apparent net asset value per share.

UK listed property companies have long been recognized that the market capitalization of property companies is less than their stated net asset value (NAV). The received wisdom has been that this discount was primarily a function of the market penalising property companies for the tax leakage they suffered. Property companies pay corporation tax on realized capital gains arising. Thus, the NAV is not necessarily what shareholders would realize in the event of a property being sold. The REIT regime has repaired the tax leak for 19 UK listed property companies; but they still suffer a NAV discount so far. The phenomenon of discount to NAV in the UK listed property companies has only been examined in a few occasions. These studies employed the "rational" approach and "noise trader" approach to examine the discount to NAV phenomenon. The "rational" approach hypothesizes that the discount to NAV as being the result of company specific factors relating to such factors as management quality, tax liability and the type of stocks held by the funds. The "noise trader" approach was associated with the work of Shiller (1989), Schleifer and Vishny (1990), and Lee, et. al. (1991). According to noise trader theory, fluctuations in departures from NAV are caused by changes in investor sentiment. That is when investors become pessimistic about future returns, the discounts are high; when investors are optimistic, the discounts are low. Average discounts exist because the unpredictability of investor sentiment impounds a risk of holding a share in addition to the risk inherent in the company's portfolio.

Adams and Venmore-Rowland (1989) are the first to address the issue of discounts for UK listed property companies, followed by Barkham and Ward (1999) who expanded the research by testing a full range of available hypotheses on a set of thirty UK listed property companies for the years of 1993 through 1995. These studies document that discounts are the result of agency costs, contingent capital gains tax and a number of other firm's specific factors. They also find the discounts result from the interaction of noise traders and rational investors. 
This research differs from these prior studies by incorporating the corporate governance mechanisms into the analysis of the discounts to NAV in the UK listed property companies. We employ a more elaborate sample consisting of 41 UK listed property companies for the years from 2005 through 2013. This sample period is particularly advantageous for two reasons. First of all, the sample period witnessed the market moving from bull to bear, the global financial crisis with the significant fall of property value; many of the property companies trade at from premium to discount, offering a widest range of divergence within a firm and across time series. Secondly, UK REIT scheme was launched since $1^{\text {st }}$ January, 2007, which was widely believed to improve the tax efficiency, therefore, the discount to NAV in the property companies should be diminishing. However, most of the REITs trade at discount. The premium/discount to NAV indicates that the stock prices of property companies reflect many factors other than the fair value and the net asset value of property companies. Listed real estate is often seen as equities rather than real estate. The listed real estate returns do not reflect direct real estate returns in the short run (one to two years), whilst listed real estate and direct real estate are more correlated or cointegrated over the medium to longer term (three and more years) (e.g. Hoesli and Oikarinen, 2012).

In this study, patterned after the prior studies, we examine a set of traditional variables of firm-specific characteristics, firm risk and the portfolio dispersion. We also control market liquidity, the more liquid the market is, the narrower the difference between share price and the underlying net asset value of a listed property company will be The primary focus is on the relationship of corporate governance practice and the level of premium/discount. We argue that good corporate governance would enhance the firm value; therefore, should reduce the discount.. To test the hypothesis, a set of principal corporate governance factors such as board structure, insider ownership and ownership concentration are employed into the tests. To the best of our knowledge, this is the first study that relates the discount to NAV in the UK. listed property companies to the corporate governance mechanisms.

The empirical analysis consists of two parts that explore the determinants of the level of and changes in premium/discount to NAV over the 2005-2013 period. First, we specify and estimate a model of cross-sectional variation in premium/discount using a 
sample of individual companies over the period of 2005-2013. We find that the level of premium/discount is negatively related to a firm's size, trading stock held for sales and focused property portfolio, but positively related to gearing, risk and sector average discount. The corporate governance factors such as board independence and institutional ownership have strong influence on premium/discount to NAV. Secondly we test the time variations in premium/discount to NAV by splitting the study period into two subperiods: up market (2005-2006) and down market (2007-2009). Changes in premium/discount over time have two common elements which are related to but not entirely explained by the risk and the independence of board of directors. The effect of corporate governance factors are more pronounced in the up market period.

The paper is arranged as follows. Section 2 reviews the literature. Data selection procedure is discussed along with description of research methodology in section 3. The statistics test results are discussed in section 4, followed by concluding remarks in section 5 .

\section{Literature review}

The UK listed property companies have long been recognized to trade at discount to NAV. However, so far there are only a couple of studies examining this puzzle over the last two decades. These studies have applied the "readily available" theories about the discount to NAV in closed-end funds to the analysis of UK. listed property companies, arguing that U. K. listed property companies have the characteristics of closed-end fund. The market value of the property portfolio the property companies hold are appraised annually and reported in the financial report. If the properties that the company holds are appreciated, the revenue of the sale of these properties is subject to capital gains tax. This capital gains tax is believed to be one of the factors that cause the discount to NAV in closed-end U.K. listed property companies. Adams and Venmore-Rowland (1989) are the first to address the issue of discount to NAV in the U. K. listed property companies. Their study finds that a reduction in contingent tax liability in the 1980s led to a reduction in average discounts. Besides the tax, they also discuss the other factors such as the added value of managers' entrepreneur skill, liquidity, capital structure risk and insider ownership as potential explanations for the property company discount, but they did not test them empirically. 
Barkham and Ward (1999) systematically examine the discount issue of thirty-nine U. K. listed property companies from 1993 through to 1995. They extend the previous study by not only empirical testing the potential factors proposed by Adams and Venmore-Rowland, they also take the market sentiment and noise-trader hypothesis into account. Their study documents that tax, firm size, holding of trading stock and historical return succeed in explaining about $15 \%$ of the cross-sectional variation. When the noise-trader hypothesis is included in the test, this factor succeeds in improving the explanatory power of their model towards $33 \%$.

Bond and Shilling (2003) and Brounen and Laak (2005) perform similar analysis in pan-European property companies' samples. These studies extend the previous research by considering the impact of company risk, value-based portfolio characteristics and index membership of a firm and help improve the understanding why some companies are undervalued by investors. For instance, Bond and Shilling (2003) analyze the discount to NAV in fifty property companies originating from eight European countries. They extend the work of Barkham and Ward (1999) by the inclusion of total risk and systematic risk and succeed in explaining around $50 \%$ of the cross-sectional variation in discounts. Their report documents positive and significant relations between discount and both types of risk. Later, Brounen and Laak (2005) examine across-section variation in NAV in seventy-two European property companies at 2002. Their study extends these prior studies by considering portfolio focus and European Public Real Estate Association (EPRA) index membership in the model specification. They report that there is significant relationship between discounts and firm's risk, size, leverage and trading liquidity. They also find that the spread of portfolio across property type increases the level of discount and the index membership matters when it comes to discount.

NAV is one of the key performance indicators used by company managers and investors to evaluate the performance of a property company. The property shares are priced in the financial market. When looking at property companies, investors in financial market are not looking at real estate. They are considering shares; the business of the company just happens to be real estate related, therefore, in the short run, the property shares are just equity, influenced by equity market and by investor 
sentiment. Investor sentiment is explained as expectations or judgements that are not fully justified by available information on market fundamentals. Investors who rely to some degree on sentiment are termed 'noise traders', who by definition misprice investments in relation to rational expectations (Shiller, 1989; De Long et al., 1990; Shleifer and Summers, 1990), so property shares may not fully reflect the underlying fundamentals of property companies.

The value of property portfolio held by the company is appraised in the property market. (more?)

Apart from the underpinning NAV of a property company, there are some other factors that could influence the market value of the company. One strand of theory that is often used to evaluate the value of a company is corporate governance practice. General finance theory is replete with empirical studies on the impact of corporate governance on firm value. There are numerous studies on the issue in real estate finance literature. Most of these studies are concerned about the US REITs. For instance, Capozza and Seguin (2003) study the impact of insider ownership on the discount to NAV in US REITs and find that higher levels of inside ownership convey a signal of higher quality management and higher REITs valuation, but lower managerial expenses, systematic risk and debt since managers have incentives to make decisions that are in their best interests if the managers retain the entire equity stake in the assets they manage; thus, the agency conflicts can be eliminated (Jensen and Meckling, 1976). Wang, et al. (1995) finds that REITs with greater institutional ownership exhibit significantly higher risk-adjusted performance. Ghosh and Sirmans (2003) examine the impact of board independence and ownership structure on the performance of US REITs. They find outside directors weakly enhance performance and the institution ownership or block ownership enhances performance. Recently, Kohl and Schaefers (2010) study the impact of corporate governance on market value of the property companies in four European countries. The market value is proxied by Tobin Q. They report that smaller board of directors, higher insider ownership and greater transparency of real estate specific disclosure would enhance a firm's value. These studies suggest that the corporate governance is rewarded by the capital market participants in terms of higher market valuations. The research of relationship of the corporate governance of UK listed property companies and corporate value is relatively scant, however there is plenty of studies of the corporate governance of UK 
listed companies. For instance Crossan (2011) studies the effect of a separation of ownership from control on 406 UK listed firms with simultaneous equations and find there is a relationship between ownership structure and firm performance. Weir and Laing (2003) analyse the board composition and ownership structures of a sample of companies that have been acquired and find the firms with the same person acting as CEO and chair, a higher proportion of non-executive directors, larger institutional shareholdings and higher director shareholdings were more likely to be acquired. They also find that small firms have higher CEO shareholdings.

Corporate governance and the role of non - executive directors in large UK companies: an empirical study, Corporate Governance: The international journal of business in society, 2004, 4(2)

This study will further extend the real estate literature by incorporating corporate governance factors to bear on the explanations of property company's premium/discount. The focus of the study is not only on explaining the premium/discount to NAV, but also the changing dynamics of $\mathrm{U}$. K. property companies value as the market transitions from up to down. This view complements the traditional set of rational explanations.

\section{Data and methodology}

The data are collected from SNL, Datastream and financial reports of the property companies. The data selection criterion requires a company to have more than five years of data available. This strict criterion maximizes the consistency over the study period, but reduces the number of companies that could be included in the final sample to 41 property companies and 335 observations. The definition of research variables are reported in Table 1.

Insert table 1.

The aim is to examine the factors that explain the divergence of property share price from NAV, with particular emphasis on corporate governance factors. The previous studies document that at the macro (or market) level the value of property share is strongly related to the value of unsecuritized property over the long-term, but not over 
the short-term (Barkham and Geltner, 1996; Wang, et al. 1997). Based on this assumption, annual discounts for each year end is computed as

$$
D I S_{i t}=\left(P_{i t}-N A V_{i t}\right) / N A V_{i t} x 100 \%
$$

Where $D I S_{i t}$ is the discount of the property company $i$ at time $t ; N A V_{i t}$ is the net asset value per share of the company ${ }^{1} ; P_{i t}$ is the price of the property company's share at the yearend day. If the share price of the underlying property company exceeds the NAV of the property company DIS $>0$ in equation 1 . The company trades at premium; otherwise, if DIS $<0$, the company trades at discount. It is possible that DIS can vary over time with changes in property market condition. For instance, if investors are opportunistic about the market, they are willing to pay a premium. The data are winsorized at $5 \%$ and $95 \%$ levels to remove the outliers.

In order to explore the factors that might explain the cross-sectional variation in the discount to NAV, we express the discount as a function of the hypothesized variables and use ordinary least squares regression in the following model.

$$
\begin{aligned}
& D_{i, t}=\beta_{0}+\beta_{1} \operatorname{SIZE}_{i, t}+\beta_{2} \text { SEAR }_{i, t}+\beta_{3} \text { TRADING }_{i, t,}+\beta_{4} \text { TAX }_{i, t}+\beta_{5} \text { RETURN }_{i, t}+ \\
& \beta_{6} \text { RISK }_{i, t}+\beta_{7} \text { SEC }_{i, t}+\beta_{8} \text { INTER }_{i, t}+\beta_{9} \text { HTYPE }_{i, t}+\beta_{m} \sum_{m=1}^{4} C G M_{m i, t}+\beta_{14} \text { REIT }_{+} e_{t}
\end{aligned}
$$

Principal corporate governance variables are denoted as $C G M_{m}$ (with $m$ ranging from one to four). $i$ denotes the individual company $i$; denotes the period $t$ for company $i$.

The tests are equipped with four model specifications. In order to understand why the vast variations exist, we start with firm specific characteristics variables in parallel with the ones used in the study of Barkham and Ward (1999). The six independent variables in the first model are defined for inclusion in the analysis. SIZE is the natural log of total assets value. Barkham and Ward argue that large companies might exhibit larger discount due to the discrete nature of asset valuation in the U. K. and be more difficult to liquidate in the market. They find larger firms have higher discount. However, the large firms may be more popular among investors and therefore allow

\footnotetext{
${ }^{1}$ NAV per share is EPRA NAV taken from company reports. No adjustments have been made. When not available, the NAV per share has been calculated as : total assets - total liabilities / number of shares outstanding.
} 
less space for price dispersions and smaller discount (Capozza and Lee, 1996; Brounen and Laak, 2005). On balance, therefore, there is no ex-ant expectation for the size. GEAR is measured to be total debt as a percentage of total assets and is expected to have a positive coefficient by virtue of the way in which the discount is calculated. There is a potential source of error arising from the treatment of property held for trading. Trading property is usually shown in the financial report as the lower of cost or net realizable value which may affect the NAV. Following Barkham and Ward, we define a variable, the trading stock held (TRADING) as a proportion of total assets and expect it to have a negative coefficient. The inherent capital gains tax liability of the property portfolio is always regarded as one of the major reasons to explain the discount to NAV in the U. K. listed property companies (Millman, 1988; Adams and Venmore-Rowland, 1989). Many property investment companies have substantial unrealized reserves as part of their capital due to the upward movement in the value of their assets. Revenue from the sale of this property is subject to taxation ${ }^{2}$. To account for this issue, we include an explanatory variable $(T A X)$, which is defined as reported contingent liability to pay tax on capital gains as a percentage of total assets and expect it to be positively related to the discount. Besides, included are market performance indicators represented by stock return of the proceeding years (RETURN) and a company's total risk (RISK). In line with Malkiel (1995) and other prior research, the monthly mean stock return over the proceeding two years is used as a proxy for a firm reputation among investors. This variable is expected to have a negative relation with discount, as investors tend to overprice strong-performing fund. Risk is measured as the standard deviation of stocks prices in the preceding year and is expected to have a positive coefficient. In model 2, property sector average discount (SECDIS) is included. SECDIS measures real estate sector average discount at the balance sheet date. Sector-wide positive or negative sentiment is an important influence on individual company's discount. This variable is expected to have positive coefficient.

We extend the study of Barkham and Ward (1999) in two ways. First, we examine the effect of property portfolio diversification on the discounts. Secondly, we employ a

\footnotetext{
${ }^{2}$ Capital gains tax is not applicable to the companies that were converted into REIT status since January, 2007. for the property companies with REIT status, the gains from selling U.K properties are exempt from tax, provided they are not held for trading or sold in the three years after completion of development.
} 
novel approach by incorporating corporate governance mechanisms into the model. The portfolio of a property company's assets can be spread across property types (offices, retail, industrial, residential and other others) and/or across border. Following (Boer, et al., 2005), we measure the portfolio spread of company $i$ to be quantified using the asset-based Herfindahl index (HTYPE). Herfindahl index adds the sum of squares of proportions in property types based on the information disclosed on annual reports.

$$
H_{t y p e, i, t}=\sum_{r \in R} S_{r, i, t}^{2}
$$

Where, $H_{t y p e, i, t}$ is Herfindahl index based on the value of property type for company $i$ at time $t . r$ represents the set of property types, $S_{r, i, t}$ is the proportion of firm $i$ 's assets invested in property sector $r$ at time $t$. A Herfindahl Index can vary between almost zero, indicating a wide spread diversification over property types and one, which indicates a complete focus of all assets in only one property type. We also construct a dummy variable for geographic diversification, that is, if a company invests across border, it equals one; otherwise, zero. Corporate diversification along the two dimensions for real estate companies is important. For instance, Ro and Ziobrowski (2011) investigate whether property type specialized U. S. REITs outperform diversified REITs by examining abnormal returns and find no evidence of superior performance associated with REITs specializing in a single property type. Brounen and Laak (2005) find that the company holding highly focused property type has low discount. It could be argued that there is no need for publicly traded property companies to hold a diversified portfolio since investors can diversify their portfolios on their own (Cronqvist, et al. 2001; Chan et al. 2003). Boer, et al. (2005) argues that within real estate sector a focused strategy increases both a firm's return and risk. Thus, on balance, no ex-ant signs are anticipated for the two diversification variables.

Empirical studies suggest that good corporate practice improves the firm value. A set of widely-accepted corporate governance mechanisms is applied. In this context, the variables to measure a company's governance strength include board size and board independence as proxies for board structure, insider ownership as proxy for incentive structure, institutional ownership as proxy for concentrated ownership. Board size (BSIZE) is measured as the number of directors on board. The board independence is 
proxied by outside directors on board. Outside directors are defined as the percentage of non-executive directors (NONEXEDIR) without family relationships to the managing board as well as representatives of companies that are not involved in related part transaction. Insider ownership (INSIDERS) is calculated as percentage of equity held by the executive management of the company. Institutional ownership (INST), the proxy for ownership concentration, is measured as the percentage of equity held by top three substantial institutions, such as pension funds, insurance companies, private equity funds or other firms that are not predominantly owned by managers or directors. These governance variables are expected to have negative coefficients.

Figure 1 displays the discounts to NAV in the property companies and the sector average discount. In 2005 and 2006, the firms included in the sample trade at premium averagely; subsequently, they trade at discount. The discount reaches 48per cent in 2008 and fall to $22 \%$ in 2009 . Compared with the property sector average discount, the companies in the sample have a much wider range of divergence of share price from NAV per share.

\section{Insert Figure 1}

Table 2 reports the summary statistics of research variables. The average discount over 2005-2009 is 2.62 per cent with a considerable across sectional variation, namely from 628.57 per cent discount to 433.33 per cent premium. The book value of total assets is $£ 179.26$ billion on average; the sample is highly skewed as evidenced by the much lower median value. The importance of insider ownership and institutional ownership is evident as they own 17.15 per cent and 24 per cent of outstanding property shares respectively. The average size of board is 8 directors, 53 per cent of whom are independent directors.

Insert table 2

\section{Results}


Before running regression tests, the explanatory data are examined using a Pearson correlations test. The results are reported in table 3 . There are some noteworthy crossrelations. For example, there are strong negative relations between discount (DIS) and trading stock (TRADING), Herfindahl index (HTYPE), board independence (NONEXEDIR) and institutional ownership (INST), but strong positive relation with risk (RISK) and sector average discount (SECDIS). Apparently, firm size (SIZE) is positively related with gearing (GEAR), return (RETURN) and risk (RISK); the large firms invest across boarder and have highly specialized property type. Large firms also have larger board size, more non-executive directors, but they have less insider equity and fewer trading stock held.

Insert table 3

Table 4 reports the OLS regression test results. In model 1, discounts are first regressed on the firm specific characteristics variables. The outputs as reported in table 4 exhibit significant relations between discounts and firm size, gearing, trading stock and risk. All signs corroborate with previous results, except for firm size, which has a negative coefficient. Consistent with Bond and Shilling (2003) and Brounen and Laak (2005), the test results document positive coefficient for the risk, indicating risk increases the discount. Contrary to Barkhan and Ward (1999), but consistent with Brounen and Laak (2005), SIZE is negatively related with the discounts, implying the largest firms have lowest discount. Larger firms are generally believed to have a more transparent disclosure, since total cost of disclosure is decreasing with firm size (Bushman, et al. 2004; Khanna, et al. 2004; Hossain, et al. 2005; Kohl and Schaefer, 2010), they are more popular among investors and therefore allow less space for price dispersions (Brounen and Laak, 2005). The tax has expected sign, but is insignificant, inconsistent with the findings by Barkham and Ward (1999) who find that contingent capital gains tax is one of the important influential factors in discounts. U. K. REIT is significantly and positively associated with discount. The objective of the REIT's regime launched in January, 2007 is to remove tax inefficiency. The benefits of REITs are that the company will not pay any corporation tax on UK investments. But U. K REITs trade at discount. However, this should be explained with caution, since the property companies started to be converted into REIT status at the time when the market turned downsize. 
Model 2 with portfolio variables included has more or less the same pattern of direction and significance amongst individual variables. $R^{2}$ increases by $3 \%$. Whilst across-boarder spread of property portfolio denoted as INTER appears to be insignificant; there is a negative and significant relation between HTYPE and its discount to NAV, in line with the findings of Brounen and Laak (2005). The sample contains a wide variation from focusing in one single property type to wide dispersion. The large U. K. listed property companies tend to have a high level of property type focus as reported in table 3. Prior research by Capozza and Seguin (1999), Cronqvist, et al. (2001) and Boer, et al. (2005) has shown that unfocused publicly traded real estate companies, particularly those diversified by property type are intransparent, very expensive to manage and ultimately less successful and a focus strategy could increase both a firm's return and risk. In Model 3, SECDIS is included. As expected, this variable has significant and positive impact on the discount, suggesting that individual property company's discount is influenced by sector-wide sentiment. Inclusion of SECDIS increases $R^{2}$ by 3 per cent to 20 per cent from 17 per cent, much lower than the result from Barkham and Ward's model in which the sector sentimental boosted 50 per cent of explanatory power.

The final step in the analysis involves the corporate governance variables of BSIZE, NONEXEDIR, INSIDERS and INST in the sample as presented on Model 4. The negative and significant relationships between discount and NONEXEDIR and INST are found. The companies with more independent directors and higher institutional ownership have lower discount to NAV. The insider ownership is negatively associated with discount, but insignificant. Inclusion of corporate governance variables in the test yields the same pattern of direction and significance among the individual variables, but $R^{2}$ increases toward to 24 per cent from 20 per cent. In other words, good corporate governance practice, that is, more independent board and higher institutional ownership, can be an important influence on a company's discount. This result is fully in line with the general finance theory, that is the good corporate governance practice can improve the value of the company and investors are willing to pay a premium to a company that have more independent board and high ownership concentration. 
Insert table 5

The study period encompasses both the run up in property prices and the subsequent down turn. To investigate the possibility that the results differ systematically in up and down market years, we re-estimate variants of the basic models separately over 2005-2006, a time of rising and /or premium to NAV and 2007-2009, a time of falling and /or discount. The results shown in table 5 and 6 are interesting in that the signs, magnitudes and statistical significance differ over the two periods for a number of the coefficients. In the up market, firm size, gearing and tax are statistically insignificant. Gearing has "wrong" sign and becomes significant in Model 4. Model 1 in table 5 reports that only three coefficients are statistically significant, those on TRADING, RETURN and RISK. The estimation of trading stock held could cause accounting issue; thus have impact on the calculation of NAV. The properties designated for trading are held in the balance sheet at the lower of cost or market value. This implies that trading stock will never be shown in the accounts above their market value but it might sometimes be below it. If assets are recorded below their market value, the calculated NAV and therefore the discount will be reduced. This effect is particularly pronounced in the up market when there are more property trading transactions. In the up market, investors are willing to pay premium for a company with good performance record proxied by proceeding three years' return. When SECDIS is included in Model 2, surprisingly, this variable is marginally insignificant. Both portfolio diversification variables are also not significantly related to discount as presented in Model 3. Inclusion of corporate governance variables increase the explanatory power of the model by 61 per cent and $R^{2}$ is boosted to 46 per cent from 18 per cent. This time, INSIDER becomes significant and negatively related to discount along with NONEXEDIR and INST. The test results show that investors are more willing to pay a premium for the company with strong corporate governance practice in the up market.

Insert table 6

Table 6 reports the test results in the down market. Unlike in the up market, SIZE and GEAR become significant and have "correct" signs. But TRADING becomes insignificant due to the thin market and less transactions. TAX becomes significant as reported in Model 1. RISK remains significant, but not RETURN. HTYPE and 
SECDIS are statistically significant as presented in Model 2 and 3. When the corporate governance variables are included in Model 4, only NONEXEDIR remains statistically significantly; all others become insignificant. Compared with the results in the up market, the explanatory power of corporate governance mechanisms becomes less dominant in the down market.

\section{Conclusions}

The property company discounts have been exhibited substantial variability over time. Through 2005-2006 the U. K. listed property companies in the sample trade at premium to NAV averagely, but since 2007 they trade at discount to NAV. This paper aims to provide new insights in the further understanding of the divergence of property share from its NAV per share cross section and over time; especially it examines the effect of corporate governance mechanisms on discounts.

We find that the level of discount to NAV is negatively related to size, trading stock, specialized property portfolio, but positively associated to gearing, risk and sector sentimental. The empirical results of the paper also find that the corporate governance practice does matter to the performance of $\mathrm{U}$. K property companies. Capital participants investing in listed property companies seem to appreciate board independence and higher levels of institutional ownership. The changes in premium/discount over time have two strong common elements across property companies, which are related to but not entirely explained by the common element in risk and board independence. These common effects are more pronounced in the up market period of 2005-2006. Overall, the results are consistent with corporate governance theory and further provide evidence that good corporate governance practices can enhance firm's value and reduce the discounts to NAV in the property companies.

\section{References}

Adams, A. \& Venmore-Rowland, P. (1989). Property share valuation. Journal of Property Valuation, 8 (2), 127-42. 
Barkham, R. J. \& Geltner, D. M. (1995). Price Discovery and Efficiency in British and American Property Markets, Real Estate Economics, 23(1), 21-44.

Barkham, R. \& Ward, C. (1999). Investor sentiment and noise traders: discount to Net Asset Value in listed property companies in the U.K. Journal of Real Estate Research, 18 (2), 291-312.

Bond, S. \& Shilling, J.D. (2003). An evaluation of property company discounts in Europe", unpublished working paper, University of Cambridge, Cambridge.

Boer, D., Brounen, D. \& H. Op't Veld, H. (2005). Corporate Focus and Stock Performance: Evidence from International Listed Property Markets, Journal of Real Estate Finance and Economics, 31(3), 263-281.

Brounen, D. \& Laak, M. (2005). Understanding the discount - evidence from European property shares. Journal of Real Estate Portfolio Management, 11 (3), 24151.

Bushman, R. M., Piotrosky, J. D., \& Smith, A. J. (2004). What determines corporate transparency? Journal of Accounting Research, 42, 207-252.

Capozza, D. \& Lee, S. (1995). Property Type, Size and REIT Value. Journal of Real Estate Research, 10, 363-379.

Capozza, D. R. \& Lee, S. (1996). Portfolio Characteristics and Net Asset Values in REITs, Canadian Journal of Economics, 29 (2), 520-26.

Capozza, D. R. \& Seguin, P. J. (1999). Focus, Transparency and Value: the REIT Evidence, Real Estate Economics, 27, 587-619.

Capozza, D.R. \& Seguin, P.J. (2003). Inside ownership, risk sharing and Tobin's qratios -evidence from REITs, Real Estate Economics, 31 (3), 367-405.

Chan, S. H., Erickson, J., \& Wang, K. (2003). Real Estate Investment Trusts: Structure, performance, and investment opportunities. New York.

Cronqvist, H., Hogfeldt, P. \& Nilsson, M. (2001). Why Agency Costs Explain Diversification Discounts, Real Estate Economics, 29, 85-126.

Crossan, K. (2011). The Effects of a Separation of Ownership from Control on UK Listed Firms: An Empirical Analysis, Managerial and decision Economics, 32: 293304.

Ghosh, C., \& Sirmans, C. F. (2003). Board independence, ownership structure and performance: evidence from real estate investment trusts. Journal of Real Estate Finance and Economics, 26, 287-318. 
Hoesli, M. \& Oikarinen, E (2012) Are REITs real estate? Evidence from international sector level data. Swiss Finance Institute Research Paper Series Number 12-15.

Hossain, M., Ahmed, K., \& Godfrey, J. M. (2005). Investment opportunity set and voluntary disclosure of prospective information: a simultaneous equations approach. Journal of Business Finance and Accounting, 32, 871-907.

Khanna, T., Palepu, K. G., \& Sirinivasan, S. (2004). Disclosure practices of foreign companies interacting with U.S. markets. Journal of Accounting Research, 42, 475508.

Kohl, N., \& Schaefers, W. (2010). Corporate governance and market valuation of publicly traded real estate companies: evidence from Europe. Journal of Real Estate Economics and Finance. DOI 10.1007/s11146-010-9236-5

Jensen,C. M \& Meckling, H. W. (1976). Theory of the firm: managerial behavior, agency costs and ownership structure. Journal of Financial Economics, 3 (4), 305360.

Lee, C.M.C., Shleifer, A., \& Thaler, A. R. H. (1991). Investor sentiment and the closed-end fund puzzle. Journal of Finance, 1991, XLVI (1), 75-109.

Malkiel, B. G. (1995). The Structure of Closed-End Fund Discounts Revisited, Journal of Portfolio Management, 32-8.

Ro, S. \& Ziobrowski, A. J. (2011). Does focus really matter? Specialized vs. diversified REITs. Journal of Real Estate Finance and Economics, 42, 68-83.

Schliefer, A. \& Vishny, R. W. (1990). Equilibrium short horizons of investors and firms. American Economic Review Papers and Proceedings, (80)2, 148-53.

Shiller, R. J. (1989). Market Volatility, MIT Press: Cambridge, MA.

Wang, K., Erickson, J., Gau, G., \& Chan, S. H. (1995). Market microstructure and real estate returns. Real Estate Economics. 23, 85-100.

Weir, C \& Laing, D. (2003), Ownership structure, board composition and the market for corporate control in the UK: an empirical analysis, Applied Economics, 35, 17471759. 
Table 1 . The definition of study variables and their expected sign

\begin{tabular}{|c|c|c|}
\hline Variables & Definition & $\begin{array}{c}\text { Expected } \\
\text { Sign }\end{array}$ \\
\hline SIZE & Natural log of total assets value & \pm \\
\hline Trading asset & $\begin{array}{l}\text { Properties held for sale as a percentage of total } \\
\text { assets }\end{array}$ & + \\
\hline Tax & $\begin{array}{l}\text { Contingent liability to pay tax on capital gains as a } \\
\text { percentage of total assets }\end{array}$ & - \\
\hline Return & Daily mean stock return over the preceding two years & + \\
\hline Risk & $\begin{array}{l}\text { Measured as the standard deviation of stocks } \\
\text { prices in the preceding year. It is winsorized at } \\
5 \% \text { and } 95 \% \text { levels. }\end{array}$ & - \\
\hline Market DIS & $\begin{array}{l}\text { Property sector discount. The data are collected from } \\
\text { EPRA. }\end{array}$ & + \\
\hline Hindex & $\begin{array}{l}\text { Herfindahl index based on value of real estate } \\
\text { type for company } i \text { at time } t\end{array}$ & \pm \\
\hline INTER & $\begin{array}{l}\text { Dummy variable: it equals } 1 \text { If the company invests } \\
\text { across boarder, otherwise } 0 \text {. }\end{array}$ & \pm \\
\hline A-B spread & $\begin{array}{l}\text { Calculated as ( Ask-Bid }) /((\text { Ask }+ \text { Bid }) / 2), \text { They are the } \\
\text { last three months ask and bid before the year end }\end{array}$ & \\
\hline BSIZE & The number of directors on board & \pm \\
\hline NON-exedir & Percentage of non-executive directors on board & + \\
\hline Insider ownership & $\begin{array}{l}\text { Natural log of percentage of shares held by the } \\
\text { executive management. }\end{array}$ & \pm \\
\hline Top three & $\begin{array}{l}\text { Natural log of percentage of equity held by top } \\
\text { three substantial shareholders }\end{array}$ & + \\
\hline REIT & $\begin{array}{l}\text { Dummy variable. If the company is REIT, it } \\
\text { equals } 1 \text {; otherwise, } 0 \text {. }\end{array}$ & + \\
\hline
\end{tabular}

Figure 1. 


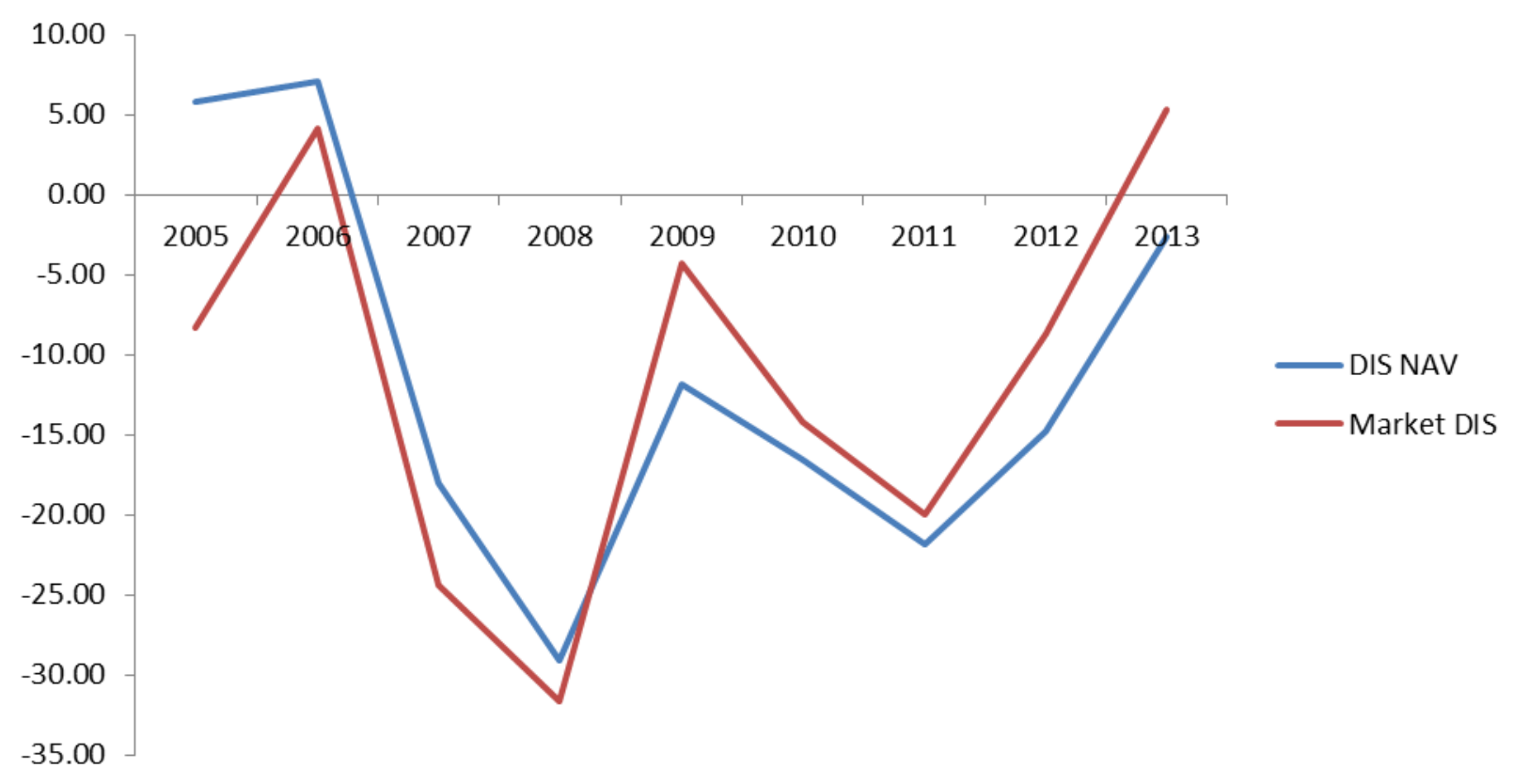

Table 2. Descriptive statistics of research variables

\begin{tabular}{|c|c|c|c|c|c|c|c|c|}
\hline & & Debt/ & Trading & & Market & & & \\
\hline & DISNAV & Assets & assets & $\operatorname{tax}$ & DIS & Risk & Return & INTER \\
\hline Mean & -11.90 & 39.03 & 3.42 & 2.49 & -11.48 & 58.07 & 2.61 & 0.23 \\
\hline Median & -11.43 & 38.68 & 0.00 & 0.17 & -11.19 & 25.30 & 5.27 & 0.00 \\
\hline Std. Dev & 21.68 & 17.98 & 7.92 & 4.42 & 12.81 & 103.32 & 21.80 & 0.42 \\
\hline Min & -42.27 & 0.00 & 0.00 & 0.00 & -35.63 & 0.24 & -29.00 & 0.00 \\
\hline \multirow[t]{2}{*}{ Max } & 19.00 & 98.59 & 51.32 & 20.32 & 10.13 & 691.03 & 33.00 & 1.00 \\
\hline & BSIZE & $\begin{array}{l}\text { Non- } \\
\text { exedir }\end{array}$ & $\begin{array}{c}\text { INSIDERS } \\
\text { ownership }\end{array}$ & $\begin{array}{c}\text { Top } \\
\text { three }\end{array}$ & Hindex & $\begin{array}{c}\text { A-B } \\
\text { Spread }\end{array}$ & $\begin{array}{c}\text { Total } \\
\text { asset } \\
\text { (billion) }\end{array}$ & REIT \\
\hline Mean & 7.84 & 60.92 & 14.63 & 25.85 & $6,032.10$ & 0.03 & 187.46 & 0.34 \\
\hline Median & 8.00 & 55.56 & 3.57 & 22.92 & $5,046.00$ & 0.01 & 65.36 & - \\
\hline Std. Dev & 2.72 & 19.60 & 18.95 & 13.12 & $2,747.19$ & 0.09 & 310.71 & 0.47 \\
\hline Min. & 3.00 & 30.77 & - & 3.50 & $1,000.00$ & 0.00 & 1.07 & - \\
\hline Max. & 15.00 & 100.00 & 67.11 & 70.33 & $10,000.00$ & 1.34 & $1,895.75$ & 1.00 \\
\hline
\end{tabular}


02/03/2016

$-21-$ 
Table 3: Pearson Correlation test of study variables

\begin{tabular}{|c|c|c|c|c|c|c|c|c|c|c|c|c|c|c|c|}
\hline & $\begin{array}{l}\text { DIS } \\
\text { NAV }\end{array}$ & LogTA & $\begin{array}{l}\text { Debt/ } \\
\text { Assets }\end{array}$ & $\begin{array}{l}\text { Trading } \\
\text { assets }\end{array}$ & Tax & $\begin{array}{l}\text { Market } \\
\text { DIS }\end{array}$ & Risk & Return & INTER & REIT & BSIZE & $\begin{array}{l}\text { Non- } \\
\text { exedir }\end{array}$ & $\begin{array}{l}\text { INSIDER } \\
\text { ownership }\end{array}$ & $\begin{array}{l}\text { Top } \\
\text { three }\end{array}$ & Hindex \\
\hline DIS NAV & 1 & & & & & & & & & & & & & & \\
\hline $\begin{array}{l}\text { LogTA } \\
\text { Debt/ }\end{array}$ & 0.21 & 1.00 & & & & & & & & & & & & & \\
\hline Assets & -0.12 & 0.19 & 1.00 & & & & & & & & & & & & \\
\hline $\begin{array}{l}\text { Trading } \\
\text { assets }\end{array}$ & 0.07 & -0.12 & 0.04 & 1.00 & & & & & & & & & & & \\
\hline Tax & -0.03 & -0.00 & -0.16 & -0.14 & 1.00 & & & & & & & & & & \\
\hline Market DIS & 0.45 & 0.03 & -0.15 & -0.02 & 0.08 & 1.00 & & & & & & & & & \\
\hline Risk & -0.05 & 0.25 & -0.15 & -0.06 & 0.25 & -0.10 & 1.00 & & & & & & & & \\
\hline Return & 0.46 & 0.06 & -0.32 & -0.01 & 0.25 & 0.43 & -0.00 & 1.00 & & & & & & & \\
\hline INTER & -0.11 & 0.26 & 0.10 & -0.14 & 0.28 & -0.00 & 0.17 & -0.08 & 1.00 & & & & & & \\
\hline REIT & 0.02 & 0.31 & -0.02 & -0.20 & -0.32 & -0.13 & 0.10 & -0.13 & 0.01 & 1.00 & & & & & \\
\hline BSIZE & 0.19 & 0.66 & 0.07 & 0.03 & -0.07 & 0.02 & 0.12 & 0.14 & 0.12 & 0.31 & 1.00 & & & & \\
\hline $\begin{array}{l}\text { Non -exedir } \\
\text { INSIDER }\end{array}$ & 0.05 & 0.10 & 0.35 & -0.19 & -0.24 & -0.00 & -0.21 & -0.13 & -0.00 & -0.24 & -0.17 & 1.00 & & & \\
\hline ownership & -0.24 & -0.34 & -0.05 & 0.01 & 0.41 & -0.05 & 0.13 & 0.04 & 0.03 & -0.18 & -0.21 & -0.33 & 1.00 & & \\
\hline Top three & -0.02 & 0.06 & 0.10 & -0.12 & -0.12 & -0.02 & -0.06 & -0.14 & -0.00 & -0.19 & -0.16 & 0.47 & -0.22 & 1.00 & \\
\hline Hindex & 0.13 & 0.10 & 0.31 & -0.05 & -0.05 & 0.00 & 0.02 & -0.00 & 0.07 & 0.11 & 0.19 & -0.04 & 0.02 & 0.02 & 1.00 \\
\hline A-B Spread & -0.24 & -0.34 & 0.21 & 0.03 & 0.01 & -0.02 & -0.10 & -0.20 & 0.06 & -0.11 & -0.28 & 0.10 & 0.13 & 0.05 & -0.09 \\
\hline
\end{tabular}

Note: Bold represents significance at $1 \%$ and $5 \%$ levels. 
Table $\mathrm{x}$. Regression

\begin{tabular}{|c|c|c|c|c|}
\hline & Model 1 & Model 2 & Model 3 & Model 4 \\
\hline \multirow[t]{2}{*}{ Constant } & -51.384 & -65.821 & -45.008 & -39.772 \\
\hline & $(-5.276)^{* * *}$ & $(-5.637)^{* * *}$ & $(-4.638)^{* * *}$ & $(-3.173)^{* * *}$ \\
\hline \multirow[t]{2}{*}{ Size } & 8.011 & 9.871 & 6.200 & 2.222 \\
\hline & $(4.772)^{* * *}$ & $(6.248)^{* * *}$ & $(3.544)^{* * *}$ & (0.89) \\
\hline \multirow[t]{2}{*}{ Debt/ Assets } & -0.208 & -0.267 & -0.115 & -0.132 \\
\hline & $(-3.164)^{* * *}$ & $(-6.501)^{* * *}$ & $(-1.766)^{*}$ & $(-1.895)^{*}$ \\
\hline \multirow[t]{2}{*}{ Trading assets } & 0.297 & 0.229 & 0.278 & 0.459 \\
\hline & $(2.022)^{* *}$ & (1.583) & $(2.206)^{* *}$ & $(3.187)^{* * *}$ \\
\hline \multirow[t]{2}{*}{ Tax } & -0.291 & 0.777 & 0.796 & 2.120 \\
\hline & $(-0.286)$ & $(0.734)$ & $(0.861)$ & $(2.290)^{* * *}$ \\
\hline \multirow[t]{2}{*}{ REIT } & & -3.469 & 2.311 & 6.084 \\
\hline & & $(-1.26)$ & $(0.968)$ & $(2.535)^{* *}$ \\
\hline \multirow[t]{2}{*}{ HType } & & 0.002 & 0.001 & 0.001 \\
\hline & & $(4.309)^{* * *}$ & $(2.566)^{* * *}$ & $(3.132)^{* * *}$ \\
\hline \multirow[t]{2}{*}{ INTER } & & -0.235 & -6.153 & -6.228 \\
\hline & & $(-3.053)^{* * *}$ & $(-2.426)^{* *}$ & $(-2.536)^{* * *}$ \\
\hline \multirow[t]{2}{*}{ Market DIS } & & & 0.535 & 0.526 \\
\hline & & & $(6.397)^{* * *}$ & $(6.473)^{* * *}$ \\
\hline \multirow[t]{2}{*}{ Risk } & & & -0.013 & -0.007 \\
\hline & & & $(-1.306)$ & $(-0.468)$ \\
\hline \multirow[t]{2}{*}{ Return } & & & 0.277 & 0.278 \\
\hline & & & $(5.186)^{* * *}$ & $(5.295)^{* * *}$ \\
\hline \multirow[t]{2}{*}{ A-B Spread } & & & -21.956 & -24.487 \\
\hline & & & $(-1.754)^{*}$ & $(-2.013)^{* *}$ \\
\hline \multirow[t]{2}{*}{ BSIZE } & & & & 0.397 \\
\hline & & & & $(0.764)$ \\
\hline \multirow{3}{*}{$\begin{array}{l}\text { Non-executive } \\
\text { directors }\end{array}$} & & & & \\
\hline & & & & 0.174 \\
\hline & & & & $(2.551)^{* * *}$ \\
\hline \multirow{3}{*}{$\begin{array}{l}\text { Log Insider } \\
\text { ownership }\end{array}$} & & & & \\
\hline & & & & -2.819 \\
\hline & & & & $(-2.01)^{* *}$ \\
\hline \multirow[t]{2}{*}{ Log Top three } & & & & 2.747 \\
\hline & & & & (0.629) \\
\hline Adjusted $\mathrm{R}^{2}$ & 0.073 & 0.211 & 0.359 & 0.383 \\
\hline F-test & 7.545 & 12.508 & 17.98 & 14.8 \\
\hline P-value & 0 & 0 & 0 & 0 \\
\hline
\end{tabular}

Note: $* * *, * *$ and $*$ represents significance at $1 \%, 5 \%$ and $10 \%$ levels. 


\begin{tabular}{|c|c|c|c|c|}
\hline & Model 1 & Model 2 & Model 3 & Model 4 \\
\hline \multirow[t]{2}{*}{ Constant } & -43.384 & -53.483 & -37.286 & -35.724 \\
\hline & $(-4.630)^{* * *}$ & $(-5.413)^{* * *}$ & $(-3.914)^{* * *}$ & $(-2.913)^{* *}$ \\
\hline \multirow[t]{2}{*}{ Size } & 7.894 & 8.88 & 6.082 & 2.746 \\
\hline & $(4.919)^{* * *}$ & $(5.157)^{* * *}$ & $(3.578)^{* * *}$ & (1.151) \\
\hline \multirow[t]{2}{*}{ Debt/ Assets } & -0.159 & -0.21 & -0.033 & -0.052 \\
\hline & $(-2.514)^{* * *}$ & $(-3.098)^{* * *}$ & $(-0.507)$ & $(-0.758)$ \\
\hline \multirow[t]{2}{*}{ Trading assets } & .262 & 0.24 & 0.281 & 0.416 \\
\hline & $(1.887)^{*}$ & $(1.716)^{*}$ & $(2.337)^{* *}$ & $(3.318)^{* * *}$ \\
\hline \multirow[t]{2}{*}{ Tax } & -1.992 & -0.93 & -0.388 & 1.166 \\
\hline & $(-2.044)^{* *}$ & $(-0.864)$ & $(-0.415)$ & (1.156) \\
\hline \multirow[t]{2}{*}{ REIT } & & 0.65 & 4.244 & 8.018 \\
\hline & & (0.241) & $(1.799)^{*}$ & $(3.142)^{* * *}$ \\
\hline \multirow[t]{2}{*}{ HType } & & 0.00 & 0.001 & 0.001 \\
\hline & & $(3.177)^{* * *}$ & $(2.397)^{* *}$ & $(2.873)^{* *}$ \\
\hline \multirow[t]{2}{*}{ INTER } & & -7.71 & -5.508 & -5.818 \\
\hline & & $(-2.659)^{* * *}$ & $(-2.165)^{* *}$ & $(-2.322)^{* *}$ \\
\hline \multirow[t]{2}{*}{ Market DIS } & & & 0.559 & 0.555 \\
\hline & & & $(6.871)^{* * *}$ & $(6.920)^{* * *}$ \\
\hline \multirow[t]{2}{*}{ Risk } & & & -0.021 & -0.013 \\
\hline & & & $(-2.160)^{* *}$ & $(-1.351)$ \\
\hline \multirow[t]{2}{*}{ Return } & & & 0.210 & 0.235 \\
\hline & & & $(3.956)^{* * *}$ & $(4.462)^{* * *}$ \\
\hline \multirow[t]{2}{*}{ A-B Spread } & & & -20.550 & -23.570 \\
\hline & & & $(-1.689)^{*}$ & $(-1.970)^{* *}$ \\
\hline \multirow[t]{2}{*}{ BSIZE } & & & & 0.183 \\
\hline & & & & $(0.370)$ \\
\hline \multirow{3}{*}{$\begin{array}{l}\text { Non-executive } \\
\text { directors }\end{array}$} & & & & \\
\hline & & & & 0.143 \\
\hline & & & & $(2.108)^{* *}$ \\
\hline \multirow{3}{*}{$\begin{array}{l}\text { Log Insider } \\
\text { ownership }\end{array}$} & & & & \\
\hline & & & & -2.204 \\
\hline & & & & $(-1.612)$ \\
\hline \multirow[t]{2}{*}{ Log Top three } & & & & 5.330 \\
\hline & & & & $(1.246)$ \\
\hline \multirow[t]{2}{*}{ Year dummy } & -14.913 & -13.30 & -10.758 & -10.474 \\
\hline & $(-5.746)^{* * *}$ & $(-5.048) * * *$ & $(-4.498)^{* * *}$ & $(-4.389)^{* * *}$ \\
\hline Adjusted $\mathrm{R}^{2}$ & 0.154 & 0.188 & 0.396 & 0.419 \\
\hline F-test & 13.203 & 10.670 & 19.248 & 16.077 \\
\hline P-value & 0 & 0 & 0 & 0 \\
\hline
\end{tabular}

